Article

\title{
Nardosinane-Type Sesquiterpenoids from the Formosan Soft Coral Paralemnalia thyrsoides
}

\section{Chiung-Yao Huang ${ }^{1}$, Jui-Hsin Su ${ }^{1,2,3}$, Bo-Wei Chen ${ }^{1}$, Zhi-Hong Wen ${ }^{1}$, Chi-Hsin Hsu ${ }^{1}$, Chang-Feng Dai ${ }^{4}$, Jyh-Horng Sheu ${ }^{1,5, *}$ and Ping-Jyun Sung ${ }^{2,3, *}$}

1 Department of Marine Biotechnology and Resources, National Sun Yat-sen University, Kaohsiung 804, Taiwan; E-Mails: betty8575@yahoo.com.tw (C.-Y.H.); x2219@nmmba.gov.tw (J.-H.S.); a6152761@yahoo.com.tw (B.-W.C.); wzh@mail.nsysu.edu.tw (Z.-H.W.); hsuch@mail.nsysu.edu.tw (C.-H.H.)

2 National Museum of Marine Biology \& Aquarium, Pingtung 944, Taiwan

3 Institute of Marine Biotechnology, National Dong Hwa University, Pingtung 944, Taiwan

4 Institute of Oceanography, National Taiwan University, Taipei 112, Taiwan; E-Mail: corallab@ntu.edu.tw

5 Division of Marine Biotechnology, Asia-Pacific Ocean Research Center, National Sun Yat-sen University, Kaohsiung 804, Taiwan

* Authors to whom correspondence should be addressed; E-Mails: sheu@mail.nsysu.edu.tw (J.-H.S.); pjsung@nmmba.gov.tw (P.-J.S.); Tel.: +886-7-525-2000 (ext. 5030) (J.-H.S.); +886-8-882-5037 (P.-J.S.); Fax: +886-7-525-5020 (J.-H.S.); +886-8-882-5087 (P.-J.S.).

Received: 11 August 2011; in revised form: 6 September 2011 / Accepted: 6 September 2011 / Published: 16 September 2011

\begin{abstract}
Five new nardosinane-type sesquiterpenoids, paralemnolins Q-U (1-5), along with three known compounds (6-8), were isolated from the Formosan soft coral Paralemnalia thyrsoides. The structures of new metabolites were elucidated on the basis of extensive spectroscopic methods, and the absolute configuration of $\mathbf{1}$ was determined by the application of Mosher's method on 1. Among these metabolites, $\mathbf{1}$ and $\mathbf{3}$ are rarely found nardosinane-type sesquiterpenoids, possessing novel polycyclic structures. Compounds 1, 3, 6 and 7 were found to possess neuroprotective activity.
\end{abstract}

Keywords: soft coral; Paralemnalia thyrsoides; nardosinane; neuroprotective activity 


\section{Introduction}

Soft corals of the genus Paralemnalia [1-7] and Lemnalia [8-12] have been found to be rich sources of sesquiterpenoids of nardosinane [1-3,9,12,13], neolemnane [3,4,10,11] and africanane-type [3,8] compounds and norsesquiterpenoids of nornardosinane-type [3,5,6,9,10] compounds. Our previous study on the secondary metabolites of a Taiwanese soft coral Paralemnalia thyrsoides, collected from the coast of Green Island, has resulted in the isolation of two norsesquiterpenoids [6], ten sesquiterpenoids [4,6,7] and three novel sesquiterpenoids derived from a nardosinane precursor [7]. In our continuing search for new and bioactive metabolites from Formosan soft corals, Paralemnalia thyrsoides collected from Orchid Island were chemically investigated for the first time, and the investigation has resulted in the isolation of five new nardosinane-type sesquiterpeneoids, paralemnolins Q-U (1-5), along with three known compounds 2-deoxylemnacarnol (6) [2], 2-deoxy-7-O-methyllemnacarnol (7) [14] and 2-oxolemnacarnol (8) [15] (Chart 1). The structures of sesquiterpenoids 1-5 were elucidated by spectroscopic analysis and the absolute configurations were established by application of modified Mosher's method on 1 [16]. The inhibitory activity of compounds 1-8 against three human cancer cell lines was investigated, however, none of these metabolites was found to possess useful cytotoxicity. Furthermore, a study of the neuroprotective effect of these metabolites revealed that 1, 3, 6 and 7, in particular 6, could reduce 6-OHDA (6-hydroxydopamine)-induced neurotoxicity in neuroblastoma SH-SY5Y cells.

Chart 1. Structures of metabolites 1-8.

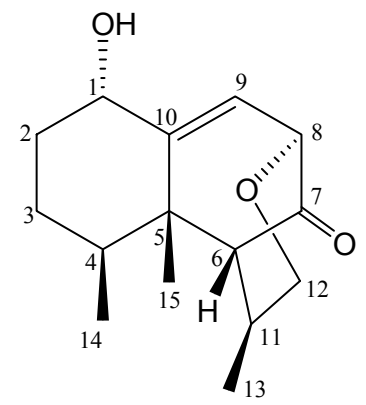

1

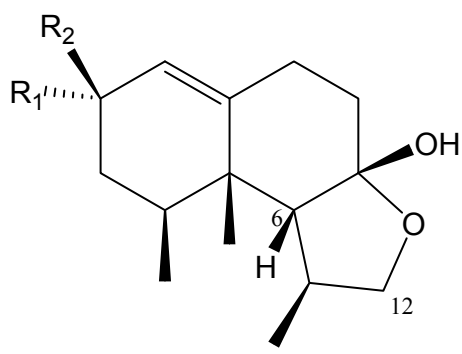

4: $\mathrm{R}_{1}=\mathrm{OOH}, \mathrm{R}_{2}=\mathrm{H}$

5: $\mathrm{R}_{1}=\mathrm{H}, \mathrm{R}_{2}=\mathrm{OOH}$

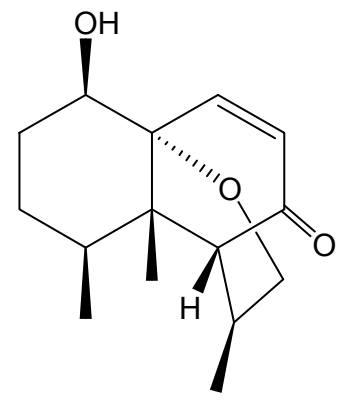

2

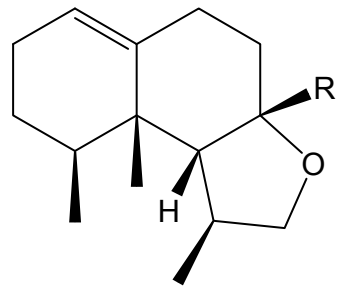

6: $\mathrm{R}=\mathrm{OH}$

7: $\mathrm{R}=\mathrm{OMe}$

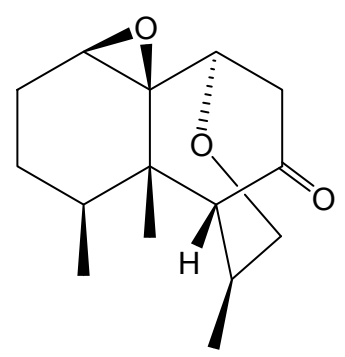

3

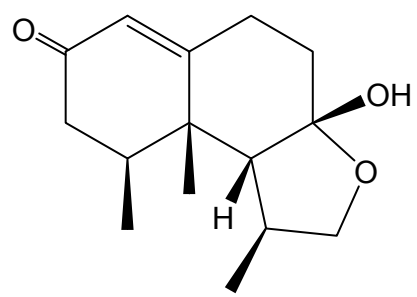

8

\section{Results and Discussion}

Paralemnolin Q (1) was obtained as a white powder. The HRESIMS $\left(\mathrm{m} / z 273.1468[\mathrm{M}+\mathrm{Na}]^{+}\right)$of $\mathbf{1}$ established the molecular formula $\mathrm{C}_{15} \mathrm{H}_{22} \mathrm{O}_{3}$, appropriate for five degrees of unsaturation, and its IR spectrum revealed the presence of carbonyl $\left(1735 \mathrm{~cm}^{-1}\right)$ and hydroxy $\left(3429 \mathrm{~cm}^{-1}\right)$ groups. The ${ }^{13} \mathrm{C} \mathrm{NMR}$ 
and DEPT (Table 1) spectroscopic data showed signals of three methyls, three $\mathrm{sp}^{3}$ methylenes (including one oxymethylene appearing at $\delta_{\mathrm{C}} 69.5$ ), five $\mathrm{sp}^{3}$ methines, one $\mathrm{sp}^{2}$ methine, one $\mathrm{sp}^{3}$ and two $\mathrm{sp}^{2}$ quaternary carbons (including one carbonyl carbon appearing at $\delta_{\mathrm{C}} 211.6$ ). The above data accounted for two of the five degrees of unsaturation, indicating a tricyclic structure for $\mathbf{1}$. From the COSY spectrum measured in $\mathrm{CDCl}_{3}$, it was possible to establish four proton sequences from $\mathrm{H}-1$ to $\mathrm{H}_{2}-3$, H-4 to $\mathrm{H}_{3}-14, \mathrm{H}-8$ to $\mathrm{H}-9$ and $\mathrm{H}-11$ to $\mathrm{H}_{3}-13$ (Figure 1). Key HMBC correlations of $\mathrm{H}-6$ to C-7; H-8 to C-7 and C-10; H-9 to C-1; $\mathrm{H}_{3}-13$ to C-6, C-11 and C-12; $\mathrm{H}_{3}-14$ to C-3, C-4 and C-5; and $\mathrm{H}_{3}-15$ to $\mathrm{C}-4, \mathrm{C}-5, \mathrm{C}-6$ and $\mathrm{C}-10$, permitted the connection of the carbon skeleton. Furthermore, the HMBC cross-peak from $\mathrm{H}-8$ to $\mathrm{C}-12$ suggested that $\mathrm{C}-8$ and $\mathrm{C}-12$ were linked through an oxygen to form a tetrahydropyran ring. On the basis of the above analysis, the gross planar structure of $\mathbf{1}$ was established.

Table 1. ${ }^{13} \mathrm{C}$ NMR data for compounds $\mathbf{1}-\mathbf{5}$.

\begin{tabular}{cccccc}
\hline Position & $\mathbf{1},{ }^{\mathrm{a}} \delta_{\mathrm{C}}$, mult. & $\mathbf{2}{ }^{\mathrm{b}} \delta_{\mathrm{C}}$, mult. & $\mathbf{3},{ }^{\mathrm{a}} \delta_{\mathrm{C}}$, mult. & $\mathbf{4},{ }^{\mathrm{a}} \delta_{\mathrm{C}}$, mult. & $\mathbf{5},{ }^{\mathrm{a}} \delta_{\mathrm{C}}$, mult. \\
\hline 1 & $69.5, \mathrm{CH}^{\mathrm{c}}$ & $73.1, \mathrm{CH}$ & $59.0, \mathrm{CH}$ & $118.5, \mathrm{CH}$ & $121.7, \mathrm{CH}$ \\
2 & $36.4, \mathrm{CH}_{2}$ & $29.4, \mathrm{CH}_{2}$ & $25.5, \mathrm{CH}_{2}$ & $77.8, \mathrm{CH}$ & $80.8, \mathrm{CH}$ \\
3 & $28.8, \mathrm{CH}_{2}$ & $24.1, \mathrm{CH}_{2}$ & $23.3, \mathrm{CH}_{2}$ & $30.5, \mathrm{CH}_{2}$ & $31.1, \mathrm{CH}_{2}$ \\
4 & $36.3, \mathrm{CH}$ & $30.0, \mathrm{CH}$ & $32.5, \mathrm{CH}$ & $29.2, \mathrm{CH}$ & $33.7, \mathrm{CH}$ \\
5 & $48.7, \mathrm{C}$ & $41.0, \mathrm{C}$ & $37.6, \mathrm{C}$ & $41.0, \mathrm{C}$ & $40.9, \mathrm{C}$ \\
6 & $60.6, \mathrm{CH}$ & $56.9, \mathrm{CH}$ & $61.6, \mathrm{CH}$ & $58.9, \mathrm{CH}$ & $59.1, \mathrm{CH}$ \\
7 & $211.6, \mathrm{C}$ & $201.8, \mathrm{C}$ & $210.6, \mathrm{C}$ & $107.3, \mathrm{C}$ & $107.5, \mathrm{C}$ \\
8 & $73.7, \mathrm{CH}$ & $133.9, \mathrm{CH}$ & $40.3, \mathrm{CH}_{2}$ & $33.2, \mathrm{CH}_{2}$ & $33.4, \mathrm{CH}_{2}$ \\
9 & $111.3, \mathrm{CH}$ & $143.6, \mathrm{CH}$ & $78.2, \mathrm{CH}$ & $27.6, \mathrm{CH}_{2}$ & $27.4, \mathrm{CH}_{2}$ \\
10 & $156.6, \mathrm{C}$ & $74.9, \mathrm{C}$ & $62.8, \mathrm{C}$ & $149.7, \mathrm{C}$ & $145.2, \mathrm{C}$ \\
11 & $35.3, \mathrm{CH}$ & $26.4, \mathrm{CH}$ & $32.0, \mathrm{CH}$ & $37.1, \mathrm{CH}$ & $37.2, \mathrm{CH}$ \\
12 & $61.9, \mathrm{CH}$ & $64.6, \mathrm{CH}_{2}$ & $67.6, \mathrm{CH}_{2}$ & $72.2, \mathrm{CH}_{2}$ & $72.2, \mathrm{CH}_{2}$ \\
13 & $18.8, \mathrm{CH}_{3}$ & $14.9, \mathrm{CH}_{3}$ & $17.2, \mathrm{CH}_{3}$ & $18.7, \mathrm{CH}_{3}$ & $18.6, \mathrm{CH}_{3}$ \\
14 & $14.2, \mathrm{CH}_{3}$ & $13.8, \mathrm{CH}_{3}$ & $14.5, \mathrm{CH}_{3}$ & $15.9, \mathrm{CH}_{3}$ & $16.3, \mathrm{CH}_{3}$ \\
15 & $19.5, \mathrm{CH}_{3}$ & $17.6, \mathrm{CH}_{3}$ & $17.7, \mathrm{CH}_{3}$ & $19.7, \mathrm{CH}_{3}$ & $21.1, \mathrm{CH}_{3}$ \\
\hline
\end{tabular}

a Spectrum recorded at $100 \mathrm{MHz}$ in $\mathrm{CDCl}_{3}$; ${ }^{\mathrm{b}} 125 \mathrm{MHz}$ in $\mathrm{CDCl}_{3}$; ${ }^{\mathrm{c}}$ Attached protons deduced by DEPT experiment.

Figure 1. Selected ${ }^{1} \mathrm{H}-{ }^{1} \mathrm{H} \operatorname{COSY}(-)$ and $\operatorname{HMBC}(\rightarrow)$ correlations of $\mathbf{1}-\mathbf{3}$.

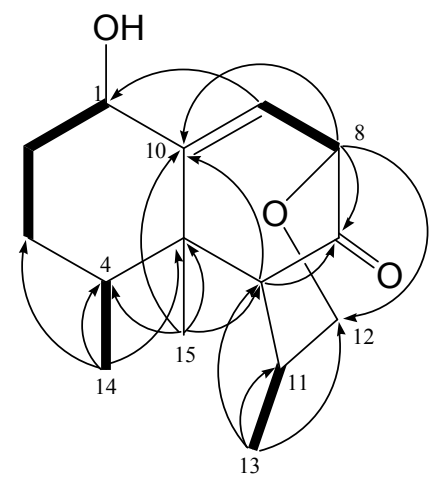

1

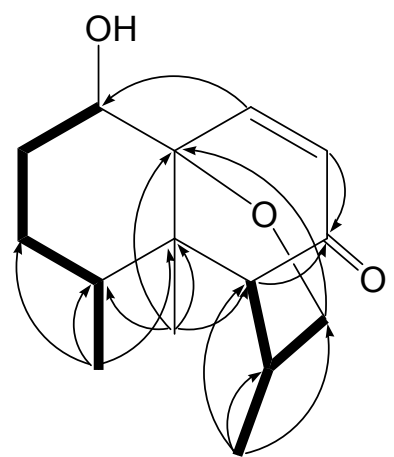

2

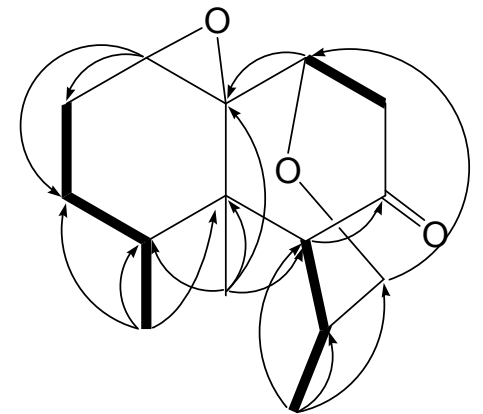

3 
The relative configuration of $\mathbf{1}$ was elucidated by the analysis of NOE correlations, as shown in Figure 2. It was found that $\mathrm{H}_{3}-15\left(\delta_{\mathrm{H}} 0.98, \mathrm{~s}\right)$ showed NOE interactions with $\mathrm{H}-1\left(\underline{\delta}_{\mathrm{H}} 4.22, \mathrm{dd}, J=12.0\right.$, $4.8 \mathrm{~Hz}), \mathrm{H}-6\left(\delta_{\mathrm{H}} 2.10\right.$, brs $)$, and $\mathrm{H}_{3}-14\left(\delta_{\mathrm{H}} 0.79, \mathrm{~d}, J=6.4 \mathrm{~Hz}\right)$; therefore, assuming the $\beta$-orientation of $\mathrm{H}_{3}-15$, all of $\mathrm{H}-1, \mathrm{H}-6$, and $\mathrm{H}_{3}-14$ should also be positioned on the $\beta$ face. Furthermore, $\mathrm{H}-4\left(\delta_{\mathrm{H}} 2.02\right.$, $\mathrm{ddq}, J=12.0,4.0,6.4 \mathrm{~Hz})$ exhibited NOE correlations with $\mathrm{H}-11\left(\delta_{\mathrm{H}} 2.39\right.$, ddq, $\left.J=3.6,3.2,7.2 \mathrm{~Hz}\right)$ and one proton of $\mathrm{H}_{2}-12\left(\delta_{\mathrm{H}} 4.18, \mathrm{dd}, J=12.0,3.2 \mathrm{~Hz}\right)$, revealing the $\alpha$-orientation of $\mathrm{H}-11$, and the $\beta$-orientations of $\mathrm{H}-8$ and $\mathrm{H}_{3}-13$. On the basis of the above findings and other detailed NOE correlations (Figure 2), the relative structure of 1 was determined. In order to resolve the absolute structure of 1 , we determined the absolute configuration at C-1 using a modified Mosher's method [15]. The $(S)$ - and $(R)$-MTPA esters of 1 (1a and 1b, respectively) were prepared using the corresponding $R$-(-)- and $S$-(+)- $\alpha$-methoxy- $\alpha$-(trifluoromethyl)phenylacetyl chlorides, respectively. The determination of the chemical shift differences $\left(\delta_{S}-\delta_{R}\right)$ for the protons neighboring $\mathrm{C}-1$ led to the assignment of the $S$ configuration at C-1 of 1 (Figure 3). Thus, the absolute configuration of 1 has been determined.

Figure 2. Key NOESY correlations for $\mathbf{1}-\mathbf{3}$.

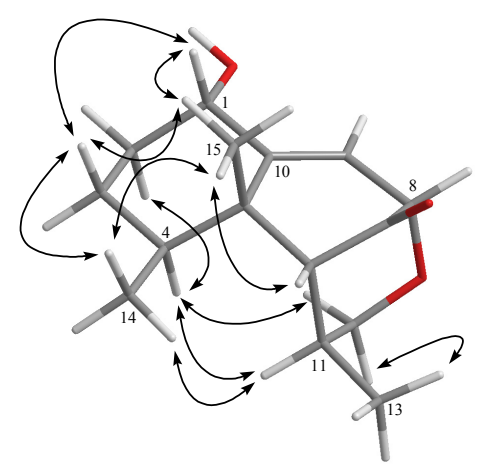

1

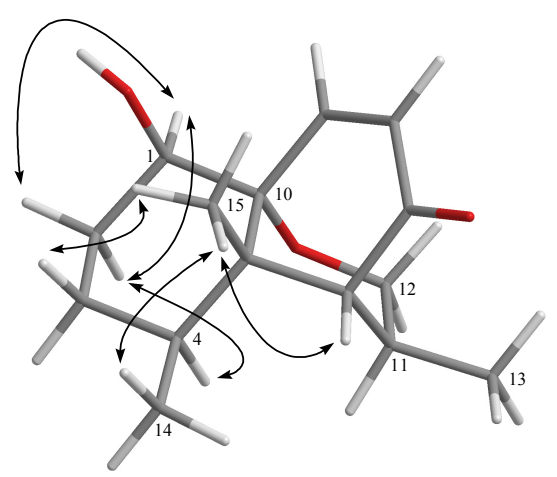

2

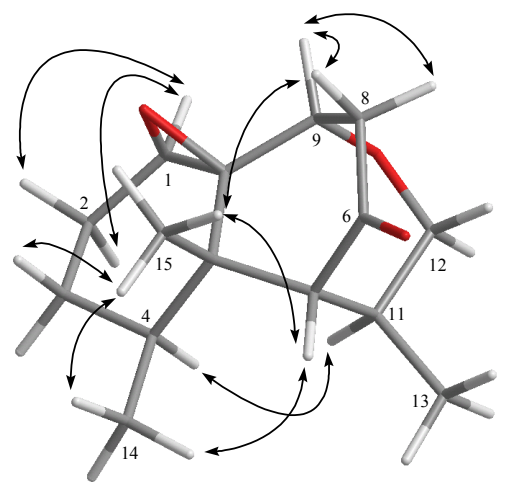

3

Figure 3. ${ }^{1} \mathrm{H}$ NMR chemical shift differences of MTPA esters of $\mathbf{1}$.

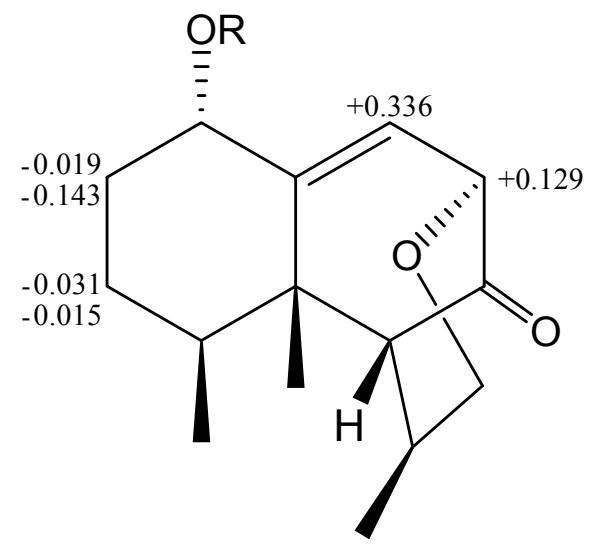

$$
\triangle \delta=\delta(S)-\delta(R) \text { MTPA ester }
$$

1a: $\mathrm{R}=(S)$-MTPA

1b: $\mathrm{R}=(R)-\mathrm{MTPA}$ 
The HRESIMS spectrum of paralemnolin R (2) showed a molecular formula of $\mathrm{C}_{15} \mathrm{H}_{22} \mathrm{O}_{3}$, the same as that of 1 . The NMR data revealed the presence of an $\alpha, \beta$-unsaturated ketone $\left(\delta_{\mathrm{C}} 201.8 \mathrm{C}\right)$, and one trisubstituted double bond $\left(\delta_{\mathrm{C}} 143.6 \mathrm{CH}, 133.9 \mathrm{CH}\right)$. The above functionalities account for two of the five degrees of unsaturation, suggesting a tricyclic structure in $2 .{ }^{1} \mathrm{H}-{ }^{1} \mathrm{H}$ COSY and $\mathrm{HMBC}$ spectra (Figure 1) further revealed that 2 possesses an $\alpha, \beta$-unsaturated ketone at $\mathrm{C}-7(\mathrm{C}=\mathrm{O}), \mathrm{C}-8$ and $\mathrm{C}-9$. Furthermore, the HMBC cross-peak from $\mathrm{H}-12$ to $\mathrm{C}-10$ suggested that $\mathrm{C}-10$ and $\mathrm{C}-12$ are linked through an oxygen. On the basis of the above observations, and by the assistance of additional 2D NMR ( ${ }^{1} \mathrm{H}-{ }^{1} \mathrm{H}$ COSY and HMBC) correlations, it was possible to establish the planar structure of 2 as illustrated in Figure 1. The relative configurations of the six chiral centers at C-1, C-4, C-5, C-6, C-10 and $\mathrm{C}-11$ in 2 were further determined on the basis of NOE correlations (Figure 2). It was found that $\mathrm{H}_{3}-15$ showed NOE interactions with both $\mathrm{H}_{3}-14$ and $\mathrm{H}-6$, while $\mathrm{H}-4$ was NOE correlated with $\mathrm{H}-11$. Therefore, $\mathrm{H}-6, \mathrm{H}_{3}-14$ and $\mathrm{H}_{3}-15$ were positioned on the same $\beta$-face, and in contrast, $\mathrm{H}-4$ and $\mathrm{H}-11$ should be placed on the $\alpha$-face. Moreover, one of the methylene protons at C-2 $\left(\delta_{\mathrm{H}} 2.18\right.$, dddd, $J=15.0,15.0,5.0,3.5 \mathrm{~Hz}$ ) exhibited NOE correlations with $\mathrm{H}-4$ and was assigned as $\mathrm{H}-2 \alpha$. The NOE correlation observed between $\mathrm{H}-2 \alpha$ and $\mathrm{H}-1$ reflected the $\beta$-orientation of hydroxy group. Further NOE analysis revealed that 2 possesses the same configurations at C-4, C-5, C-10, and C-11, as in known compounds flavalins B-D [12]. Thus, the structure of 2 was fully established.

The HRESIMS of paralemnolin S (3) showed that it possesses the molecular formula $\mathrm{C}_{15} \mathrm{H}_{22} \mathrm{O}_{3}$ $\left(\mathrm{m} / \mathrm{z} 251.1634[\mathrm{M}+\mathrm{H}]^{+}\right)$. The IR spectrum of 3 showed the absorption of a carbonyl group $\left(1719 \mathrm{~cm}^{-1}\right)$. The NMR data showed the presence of one trisubstituted epoxide $\left(\delta_{\mathrm{H}} 3.31,1 \mathrm{H}\right.$, brs; $\delta_{\mathrm{C}} 62.8, \mathrm{C}$ and 59.0, $\mathrm{CH})$, and one ketone $\left(\delta_{\mathrm{C}} 210.6, \mathrm{C}\right)$. The above functionalities and ${ }^{1} \mathrm{H}$ and ${ }^{13} \mathrm{C} \mathrm{NMR}$ spectroscopic data (Tables 1 and 2) showed a polycyclic structure in 3. On the basis of the above results and by the assistance of ${ }^{1} \mathrm{H}-{ }^{1} \mathrm{H}$ COSY and HMBC spectroscopic analyses (Figure 1), the molecular framework of 3 could be established. This metabolite was found to be a rare nardosinane containing an oxacycloheptane. The $4 S^{*}, 5 S^{*}, 11 R^{*}$ configurations of $\mathbf{3}$ were revealed from the similar NOE interactions (Figure 2) as in $\mathbf{1}$ and $\mathbf{2}$. Moreover, by NOESY spectrum (Figure 2), it was found that the $\alpha$-oriented $\mathrm{H}-1$ showed NOE interactions with $\mathrm{H}_{2}-2$, but not with $\mathrm{H}_{3}-15$, indicating the $\alpha$-orientation of $\mathrm{H}-1$. Furthermore, the NOE correlation observed between one proton $\left(\delta_{\mathrm{H}} 2.80\right.$, dd, $\left.J=19.2,2.8 \mathrm{~Hz}\right)$ of $\mathrm{H}_{2}-8$ with $\mathrm{H}_{3}-15$ and $\mathrm{H}-9$ reflected the $\beta$-orientation of H-9. From the above evidences and the other NOE correlations (Figure 3), the structure of 3 was determined.

The HRESIMS of paralemnolin $\mathrm{T}$ (4) showed that it possesses the molecular formula $\mathrm{C}_{15} \mathrm{H}_{24} \mathrm{O}_{4}$ $\left(\mathrm{m} / \mathrm{z} 269.1742[\mathrm{M}+\mathrm{H}]^{+}\right)$. The IR spectrum of 4 showed the absorption of a hydroxy group $\left(3361 \mathrm{~cm}^{-1}\right)$. Comparison of the ${ }^{1} \mathrm{H}$ and ${ }^{13} \mathrm{C}$ NMR spectroscopic data (Tables 1 and 2) of compounds 4 and 8 [15] suggested that the structure of $\mathbf{4}$ should be very similar to that of $\mathbf{8}$, with the exception of signals assigned to $\mathrm{C}-2$, where a ketone $\left(\delta_{\mathrm{C}} 198.0, \mathrm{C}\right)$ in $\mathbf{8}$ was replaced by one hydroperoxy-bearing methine $\left(\delta_{\mathrm{H}} 4.37,1 \mathrm{H}, \mathrm{t}, J=4.0 \mathrm{~Hz}, \delta_{\mathrm{C}} 77.8, \mathrm{CH}\right)$ in 4 . Furthermore, $\mathrm{H}_{3}-15$ was found to show NOE correlations with $\mathrm{H}-6, \mathrm{H}_{3}-14$ which further correlates with $\mathrm{H}_{3}-13$, and one proton of $\mathrm{H}_{2}-3\left(\delta_{\mathrm{H}} 1.57\right.$, m), and the other proton of $\mathrm{H}_{2}-3\left(\delta_{\mathrm{H}} 1.93, \mathrm{~m}\right)$ showed an NOE correlation with hydroperoxy proton $\left(\delta_{\mathrm{H}} 7.83\right.$, brs), suggesting that $\mathrm{H}-2, \mathrm{H}-6, \mathrm{H}_{3}-13, \mathrm{H}_{3}-14$ and $\mathrm{H}_{3}-15$ should be placed on the same $\beta$-face and in contrast, hydroperoxy group should be positioned on the $\alpha$-face. Further analysis of other NOE correlations revealed that 4 possesses the same relative configurations at C-4, C-5, C-6, C-7 and C-11 as those of 8 (Figure 4). Based on the above results, the structure of $\mathbf{4}$ was established. 
Table 2. ${ }^{1} \mathrm{H}-\mathrm{NMR}$ spectral data for compounds $\mathbf{1}-\mathbf{5}$.

\begin{tabular}{|c|c|c|c|c|c|}
\hline Position & $1,{ }^{\mathrm{a}} \delta_{\mathrm{H}}(J \text { in } \mathrm{Hz})^{\mathrm{c}}$ & $2,{ }^{\mathrm{b}} \delta_{\mathrm{H}}(J$ in $\mathrm{Hz})$ & $\mathbf{3},{ }^{\mathrm{a}} \delta_{\mathrm{H}}(J$ in $\mathrm{Hz})$ & $4,{ }^{\mathrm{a}} \delta_{\mathrm{H}}(J$ in $\mathrm{Hz})$ & $\mathbf{5},{ }^{\text {a }} \delta_{\mathrm{H}}(J$ in $\mathrm{Hz})$ \\
\hline 1 & $4.22, \mathrm{dd}(12.0,4.8)^{\mathrm{c}}$ & 3.81 , brs & 3.31 , brs & $5.57, \mathrm{dd}(4.0,1.6)$ & 5.60 , brs \\
\hline \multirow[t]{4}{*}{2} & 2.19, dddd & 2.18 , dddd & 2.19, dddd & $4.37, \mathrm{t}(4.0)$ & $4.59, \mathrm{t}(7.2)$ \\
\hline & $(14.0,4.8,2.4,2.4)$ & $(15.0,15.0,5.0,3.5)$ & $(15.6,4.8,2.4,2.4)$ & & \\
\hline & $1.48, \mathrm{~m}$ & $1.65, \mathrm{~m}$ & 1.92, dddd & & \\
\hline & & & $(15.6,12.0,6.0,1.6)$ & & \\
\hline \multirow[t]{3}{*}{3} & $1.74, \mathrm{ddd}$ & $1.70, \mathrm{~m}$ & $1.37, \mathrm{~m}$ & $1.93, \mathrm{~m}$ & $1.84, \mathrm{~m}$ \\
\hline & $(14.0,4.0,4.0,4.0)$ & & & & \\
\hline & $1.57, \mathrm{~m}$ & $1.37, \mathrm{~m}$ & $1.24, \mathrm{~m}$ & $1.57, \mathrm{~m}$ & $1.56, \mathrm{~m}$ \\
\hline \multirow[t]{2}{*}{4} & $2.02, \mathrm{ddq}$ & $2.55, \mathrm{ddq}$ & $1.73, \mathrm{ddq}$ & $2.02, \mathrm{ddq}$ & $1.95, \mathrm{~m}$ \\
\hline & $(12.0,4.0,6.4)$ & $(15.5,3.5,7.0)$ & $(12.4,2.8,6.8)$ & $(12.8,3.2,6.8)$ & \\
\hline 6 & $2.10, \mathrm{brs}$ & $2.25, \mathrm{~d}(5.0)$ & $2.40, \mathrm{~m}$ & $1.82, \mathrm{~m}$ & $1.80, \mathrm{~m}$ \\
\hline \multirow[t]{2}{*}{8} & $4.10, \mathrm{~d}(6.4)$ & $6.39, \mathrm{~s}$ & $2.80, \mathrm{dd}(19.2,2.8)$ & $1.94, \mathrm{~m}$ & $1.95, \mathrm{~m}$ \\
\hline & & & $2.64, \mathrm{dd}(19.2,2.8)$ & $1.82, \mathrm{~m}$ & $1.79, \mathrm{~m}$ \\
\hline 9 & $5.77, \mathrm{dd}(6.4,2.4)$ & $6.39, \mathrm{~s}$ & $3.53, \mathrm{t}(2.8)$ & $2.44, \mathrm{~m} ; 2.30, \mathrm{~m}$ & $2.46, \mathrm{~m} ; 2.26, \mathrm{~m}$ \\
\hline \multirow[t]{2}{*}{11} & $2.39, \mathrm{ddq}$ & $2.36, \mathrm{~m}$ & $2.38, \mathrm{~m}$ & $1.92, \mathrm{~m}$ & $1.91, \mathrm{~m}$ \\
\hline & $(3.6,3.2,7.2)$ & & & & \\
\hline \multirow[t]{2}{*}{12} & $4.18, \mathrm{dd}(12.0,3.2)$ & $3.75, \mathrm{dd}(12.5,6.5)$ & $3.81, \mathrm{dd}(13.2,4.8)$ & $3.87, \mathrm{t}(8.8)$ & $3.88, \mathrm{t}(8.8)$ \\
\hline & $3.38, \mathrm{dd}(12.0,1.2)$ & $3.19, \mathrm{dd}(12.5,12.5)$ & $3.31, \mathrm{dd}(13.2,9.6)$ & $3.48, \mathrm{t}(8.8)$ & $3.49, \mathrm{t}(8.8)$ \\
\hline 13 & $1.10, \mathrm{~d}(7.2)$ & $0.70, \mathrm{~d}(7.0)$ & $0.93, \mathrm{~d}(7.2)$ & $1.10, \mathrm{~d}(5.2)$ & $1.09, \mathrm{~d}(6.0)$ \\
\hline 14 & $0.79, \mathrm{~d}(6.4)$ & $0.75, \mathrm{~d}(7.0)$ & $0.76, \mathrm{~d}(6.8)$ & $0.90, \mathrm{~d}(6.8)$ & $0.92, \mathrm{~d}(6.8)$ \\
\hline 15 & $0.98, \mathrm{~s}$ & $1.06, \mathrm{~s}$ & $0.87, \mathrm{~s}$ & $1.11, \mathrm{~s}$ & $1.18, \mathrm{~s}$ \\
\hline
\end{tabular}

Figure 4. Key NOE correlations of $\mathbf{4}$ and $\mathbf{5}$.

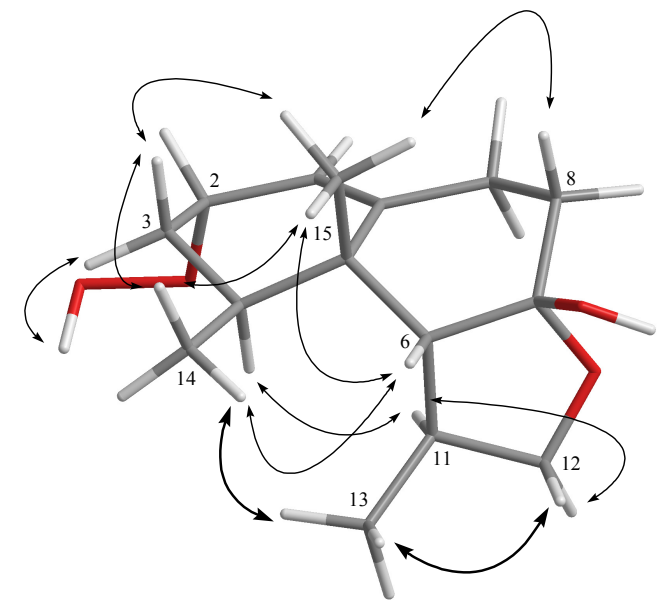

4

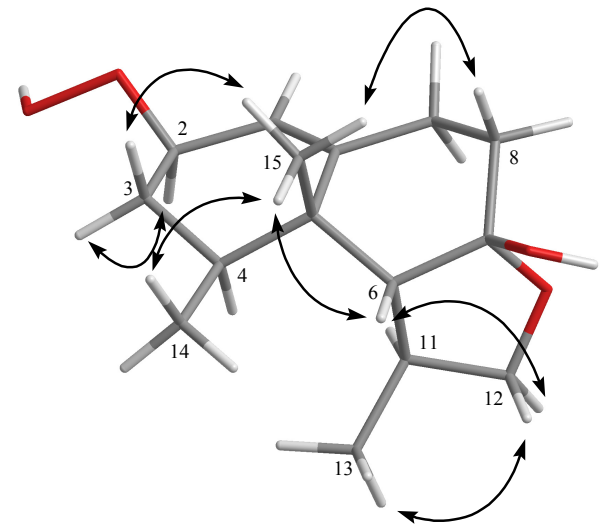

5

Paralemnolin U (5) was isolated as a white solid. Its HRESIMS exhibited a $[\mathrm{M}+\mathrm{H}]^{+}$ion peak at $269.1746 \mathrm{~m} / \mathrm{z}$, establishing a molecular formula of $\mathrm{C}_{15} \mathrm{H}_{24} \mathrm{O}_{4}$. By $2 \mathrm{D}$ NMR spectroscope data, including COSY, HMQC, and HMBC, compound 5 was shown to possess the same molecular framework as that of $\mathbf{4}$. Furthermore, the NMR data of $\mathbf{5}$ were very similar to those of $\mathbf{4}$, suggesting that 5 is an isomer of 4. By NOESY spectrum (Figure 2), it was found that the $\beta$-oriented $\mathrm{H}_{3}-15$ 
showed NOE correlations with one proton of $\mathrm{H}_{2}-3\left(\delta_{\mathrm{H}} 1.56, \mathrm{~m}\right)$ and the other proton of $\mathrm{H}_{2}-3\left(\delta_{\mathrm{H}} 1.84, \mathrm{~m}\right)$ showed NOE correlation with $\mathrm{H}-2$, indicating the $\beta$-orientation of the hydroperoxy group. On the basis of the above findings and other NOE correlations (Figure 4), 5 was revealed to be the C-2 epimer of 4.

In order to explore the biological activities of the isolated compounds, cytotoxicity of these compounds against the proliferation of a limited panel of cancer cell lines, including mouse melanoma (B16), human epithelial carcinoma (HeLa), human hepatoma carcinoma (HepG2) cell lines, was evaluated. The results showed that all of the compounds were not cytotoxic toward the above cancer cells $\left(\mathrm{IC}_{50}\right.$ 's $\left.>20 \mu \mathrm{g} / \mathrm{mL}\right)$. Furthermore, the neuroprotective assay of 1-8 using 6-OHDA-induced neurotoxicity in neuroblastoma SHSY5Y, a human dopaminergic neuron often used for study of Parkinson's disease [17], was performed by a method reported previously [18]. It was observed that the cytotoxicity of 6-OHDA on SH-SY5Y cells could be reduced by pretreatment with 1, 3, 6 and 7 at various concentrations. The relative neuroprotective activities of 1 at $10^{-2}, 10^{-1}, 1$ and $10 \mu \mathrm{M}$ were $8.7 \pm 2.5,20.2 \pm 14.0,16.2 \pm 3.5$ and $11.2 \pm 1.3 \%, 3$ at $10^{-4}, 10^{-3}, 10^{-2}$ and $10^{-1} \mu \mathrm{M}$ were $6.1 \pm 2.6$, $16.2 \pm 5.1,25.2 \pm 3.4$ and $10.2 \pm 5.3 \%, 6$ at $10^{-2}, 10^{-1}, 1$ and $10 \mu \mathrm{M}$ were $10.1 \pm 1.9,44.8 \pm 4.5$, $30.2 \pm 1.2$ and $38.9 \pm 2.7 \%$, and 7 at $10^{-4}, 10^{-3}$ and $10^{-2} \mu \mathrm{M}$ were $13.5 \pm 3.5,24.5 \pm 7.9$ and $16.7 \pm 2.2 \%$, respectively (Figure 5). From the neurological activity results, we suggest that further investigation of 1, 3, 6 and 7 for their therapeutic potential against neurodegenerative diseases is worthwhile.

Figure 5. The neuroprotective effects of 1, 3, 6 and 7 on 6-OHDA-induced neurotoxicity in human neuroblastoma SH-SY5Y cells. SH-SY5Y cells were pre-incubated for $1 \mathrm{~h}$ with the indicated concentration of test compound and then stimulated with 6-OHDA $(20 \mu \mathrm{M})$ or vehicle. Relative neuroprotection of control (without the treatment of 6-OHDA and compound) and 6-OHDA-treated alone group were taken to be $100 \%$ and $0 \%$, respectively. The experiment was repeated three times. * Significantly different from the 6-OHDA-treated alone group $(P<0.05)$.

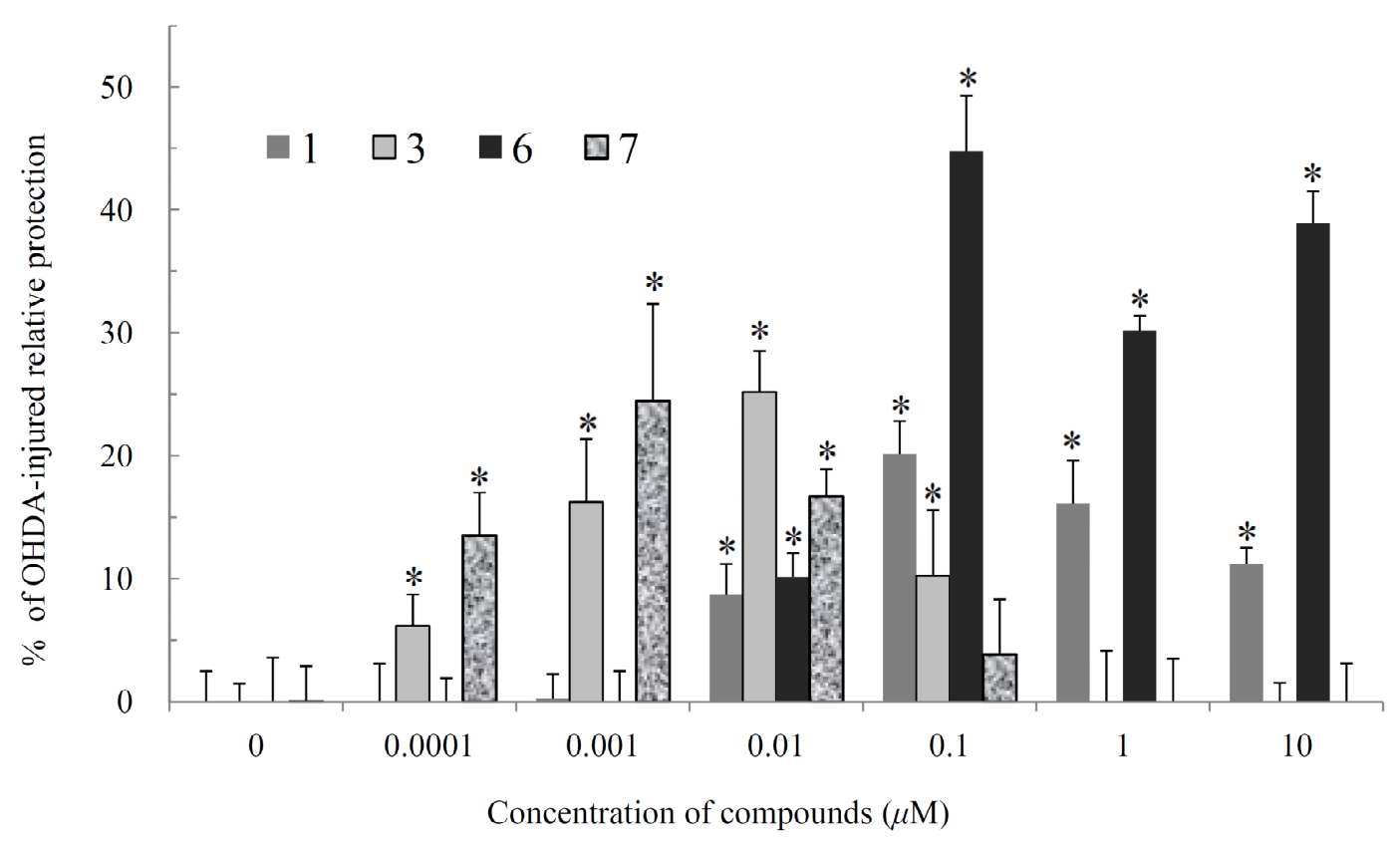




\section{Experimental Section}

\subsection{General Experimental Procedures}

Melting points were determined using a Fisher-Johns melting point apparatus. Optical rotations were measured on a JASCO P-1020 polarimeter. Ultraviolet spectrum was recorded on a JASCO V-650 spectrophotometer. IR spectra were recorded on a JASCO FT/IR-4100 infrared spectrophotometer. The NMR spectra were recorded on a Varian 400MR FT-NMR (or Varian Unity INOVA500 FT-NMR) instrument at $400 \mathrm{MHz}$ (or $500 \mathrm{MHz}$ ) for ${ }^{1} \mathrm{H}$ and $100 \mathrm{MHz}$ (or $125 \mathrm{MHz}$ ) for ${ }^{13} \mathrm{C}$ in $\mathrm{CDCl}_{3}$. ESIMS data were obtained with a Finnigan LCQ ion-trap mass spectrometer. HRESIMS data were recorded on a LTQ Orbitrap XL mass spectrometer. Silica gel (Merck, 230-400 mesh) was used for column chromatography. Precoated silica gel plates (Merck, Kieselgel 60 F-254, $0.2 \mathrm{~mm}$ ) were used for analytical TLC. High-performance liquid chromatography was performed on a Hitachi L-2455 HPLC apparatus with a Supelco C18 column $(250 \times 21.2 \mathrm{~mm}, 5 \mu \mathrm{m})$.

\subsection{Animal Material}

Soft coral P. thyrsoide was collected by hand using SCUBA off the coast of Orchid Island, located off Taiwan's southeastern coast, in August 2008, at a depth of 10-15 m, and stored in a freezer until extraction. A voucher sample was deposited at the Department of Marine Biotechnology and Resources, National Sun Yat-sen University.

\subsection{Extraction and Separation}

The frozen bodies of $P$. thyrsoide $(3.1 \mathrm{~kg}$, wet $\mathrm{wt})$ were sliced and exhaustively extracted with dichloromethane $(1 \times 10 \mathrm{~L})$. The EtOAc extract $(30.4 \mathrm{~g})$ was chromatographed over silica gel by column chromatography and eluting with EtOAc in $n$-hexane $(0-100 \%$, stepwise) then with acetone in EtOAc (50-100\%, stepwise) to yield 30 fractions. Fraction 21, eluting with $n$-hexane-EtOAc (2:1), was further purified over silica gel using $n$-hexane-acetone (7:1) to afford six subfractions (A1-A6). Subfraction A2 was separated by reversed-phase HPLC using $\mathrm{MeOH}-\mathrm{H}_{2} \mathrm{O}$ (4:1) to afford 4 (1.8 mg), $5(0.6 \mathrm{mg}), \mathbf{6}(18.3 \mathrm{mg})$ and $7(8.8 \mathrm{mg})$, and subfraction A4 was separated by reversed-phase HPLC using $\mathrm{MeOH}-\mathrm{H}_{2} \mathrm{O}(2: 1)$ to afford $\mathbf{1}(10.2 \mathrm{mg}), 2$ (14.6 mg), $3(0.8 \mathrm{mg})$ and 8 (5.1 mg).

Paralemnolin Q (1): white solid; $\mathrm{mp} 118{ }^{\circ} \mathrm{C}$; $[\alpha]^{26}{ }_{\mathrm{D}}+26\left(c 0.24, \mathrm{CHCl}_{3}\right)$; IR (neat) $v_{\max } 3429$, 2963, 2931, 2877 and $1735 \mathrm{~cm}^{-1} ;{ }^{13} \mathrm{C}$ and ${ }^{1} \mathrm{H}$ NMR data, see Tables 1 and 2; ESIMS $\mathrm{m} / z 273$ $[\mathrm{M}+\mathrm{Na}]^{+}$; HRESIMS $m / z 273.1468[\mathrm{M}+\mathrm{Na}]^{+}$(calcd for $\mathrm{C}_{15} \mathrm{H}_{22} \mathrm{O}_{3} \mathrm{Na}, 273.1467$ ).

Paralemnolin R (2): white solid; mp $120{ }^{\circ} \mathrm{C}$; $[\alpha]^{26}{ }_{\mathrm{D}}-42$ (c 1.46, $\left.\mathrm{CHCl}_{3}\right)$; UV (MeOH) $\lambda_{\max } 211$ ( $\log \varepsilon=3.5$ ); IR (neat) $v_{\max } 3401,2960,2937$ and $1654 \mathrm{~cm}^{-1} ;{ }^{13} \mathrm{C}$ and ${ }^{1} \mathrm{H}$ NMR data, see Tables 1 and 2; ESIMS $m / z 273[\mathrm{M}+\mathrm{Na}]^{+}$; HRESIMS $m / z 273.1465[\mathrm{M}+\mathrm{Na}]^{+}$(calcd for $\mathrm{C}_{15} \mathrm{H}_{22} \mathrm{O}_{3} \mathrm{Na}, 273.1467$ ).

Paralemnolin S (3): colorless oil; $[\alpha]^{24}{ }_{\mathrm{D}}+83\left(c 0.08, \mathrm{CHCl}_{3}\right)$; IR (neat) $v_{\max } 2958,2933,2881,1719$ and $1676 \mathrm{~cm}^{-1} ;{ }^{13} \mathrm{C}$ and ${ }^{1} \mathrm{H}$ NMR data, see Table 1; ESIMS $m / z 251[\mathrm{M}+\mathrm{H}]^{+}$; HRESIMS $m / z 251.1634[\mathrm{M}+\mathrm{H}]^{+}$(calcd for $\mathrm{C}_{15} \mathrm{H}_{23} \mathrm{O}_{3}, 251.1642$ ). 
Paralemnolin T (4): colorless oil; $[\alpha]^{24}-28$ (c 0.18, $\mathrm{CHCl}_{3}$ ); IR (neat) $v_{\max } 3361,2933,2881$ and $1652 \mathrm{~cm}^{-1} ;{ }^{13} \mathrm{C}$ and ${ }^{1} \mathrm{H}$ NMR data, see Table 1; ESIMS $m / z 269[\mathrm{M}+\mathrm{H}]^{+}$; HRESIMS $m / z 269.1742$ $[\mathrm{M}+\mathrm{H}]^{+}$(calcd for $\mathrm{C}_{15} \mathrm{H}_{25} \mathrm{O}_{4}, 269.1747$ ).

Paralemnolin U (5): colorless oil; $[\alpha]^{24}-140\left(c 0.06, \mathrm{CHCl}_{3}\right)$; IR (neat) $v_{\max } 3365,2937,2877$ and $1652 \mathrm{~cm}^{-1} ;{ }^{13} \mathrm{C}$ and ${ }^{1} \mathrm{H}$ NMR data, see Table 1; ESIMS $m / z 269[\mathrm{M}+\mathrm{H}]^{+}$; HRESIMS $m / z 269.1746$ $[\mathrm{M}+\mathrm{H}]^{+}$(calcd for $\mathrm{C}_{15} \mathrm{H}_{25} \mathrm{O}_{4}, 269.1747$ ).

Preparation of $(S)$ - and $(R)$-MTPA esters of $\mathbf{1}$. To a solution of $\mathbf{1}(1.0 \mathrm{mg})$ in pyridine $(0.1 \mathrm{~mL})$ was added $(R)$-MTPA chloride $(10 \mu \mathrm{L})$, and the mixture was allowed to stand for $12 \mathrm{~h}$ at room temperature. After the evaporation of the solvent, the residue was subjected to short silica gel column chromatography using $n$-hexane-acetone (6:1) to yield the $(S)$-MTPA ester, 1a $(0.4 \mathrm{mg})$. The same procedure was applied to obtain the $(R)$-MTPA ester $\mathbf{1 b}(0.9 \mathrm{mg})$ from the reaction of (S)-(+)- $\alpha$-methoxy- $\alpha$-(trifluoromethyl)phenylacetyl chloride with 1. Selective ${ }^{1} \mathrm{H}-\mathrm{NMR}\left(\mathrm{CDCl}_{3}\right.$, $400 \mathrm{MHz})$ data of 1a: $\delta 2.237(1 \mathrm{H}, \mathrm{m}, \mathrm{H}-2 \mathrm{a}), 1.513(1 \mathrm{H}, \mathrm{m}, \mathrm{H}-2 \mathrm{~b}), 1.757(1 \mathrm{H}, \mathrm{m}, \mathrm{H}-3 \mathrm{a}), 1.641$ (1H, m, H-3b), 2.123 (1H, brs, H-6), $3.992(1 \mathrm{H}, \mathrm{d}, J=6.4 \mathrm{~Hz}, \mathrm{H}-8), 5.488$ (1H, dd, $J=6.4,2.0 \mathrm{~Hz}, \mathrm{H}-9)$, $1.091(3 \mathrm{H}, \mathrm{d}, J=6.8 \mathrm{~Hz}, \mathrm{H}-13), 0.801(3 \mathrm{H}, \mathrm{d}, J=6.8 \mathrm{~Hz}, \mathrm{H}-14), 1.046$ (3H, s, H-15); selective ${ }^{1} \mathrm{H}$ NMR $\left(\mathrm{CDCl}_{3}, 400 \mathrm{MHz}\right)$ data of $\mathbf{1 b}: \delta 2.256(1 \mathrm{H}, \mathrm{m}, \mathrm{H}-2 \mathrm{a}), 1.656(1 \mathrm{H}, \mathrm{m}, \mathrm{H}-2 \mathrm{~b}), 1.788(1 \mathrm{H}, \mathrm{m}$, H-3a), $1.656(1 \mathrm{H}, \mathrm{m}, \mathrm{H}-3 \mathrm{~b}), 2.106(1 \mathrm{H}, \mathrm{brs}, \mathrm{H}-6), 3.863(1 \mathrm{H}, \mathrm{d}, J=6.8 \mathrm{~Hz}, \mathrm{H}-8), 5.152$ (1H, dd, $J=6.4,2.0 \mathrm{~Hz}, \mathrm{H}-9), 1.078(3 \mathrm{H}, \mathrm{d}, J=6.8 \mathrm{~Hz}, \mathrm{H}-13), 0.804(3 \mathrm{H}, \mathrm{d}, J=6.8 \mathrm{~Hz}, \mathrm{H}-14), 1.038(3 \mathrm{H}$, $\mathrm{s}, \mathrm{H}-15)$.

\subsection{Cytotoxicity Testing}

Cell lines were purchased from the American Type Culture Collection (ATCC). Cytotoxicity assays of compounds 1-8 were performed using the Alamar Blue assay $[19,20]$.

\subsection{Neuroprotective Activity Assay}

The method for neuroprotective assay was modified from previous study [18]. The human neuroblastoma SH-SY5Y cell line was cultured on 96-well plates. Compounds $\mathbf{1}-\mathbf{8}$ were added to the cells $1 \mathrm{~h}$ before $20 \mu \mathrm{M}$ 6-hydroxydopamine (6-OHDA) challenge. After $15 \mathrm{~h}$ incubation, $10 \mu \mathrm{L}$ of Alamar Blue (Biosource, CA, USA) was aseptically added. The percentages of neuroprotection in 6-OHDA alone and control (without 6-OHDA and test compounds) groups were defined as $0 \%$ and $100 \%$, respectively.

\section{Conclusions}

Our present investigation demonstrated that the Formosan soft coral Paralemnalia thyrsoides is a good source of bioactive substances. In our investigation of new and bioactive metabolites from the Formosan soft corals, this is the first study of $P$. thyrsoides collected from Orchid Island. From the neurological activity results, compounds 1, 3, 6 and 7, in particular 6, deserve further study for therapeutic potential against neurodegenerative diseases. 


\section{Acknowledgements}

This work was supported by grants from the Ministry of Education (99C031702) and National Science Council of Taiwan (NSC 98-2113-M-110-002-MY3) awarded to J.-H.S.

\section{References}

1. Su, J.Y.; Zhong, Y.L.; Zeng, L.M. Two new sesquiterpenoids from the soft coral Paralemnalia thyrsoides. J. Nat. Prod. 1993, 56, 288-291.

2. Bowden, B.F.; Coll, J.C.; Mitchell, S.J. Studies of Australian soft corals. XIX. Two new sesquiterpenes with the nardosinane skeleton from a Paralemnalia species. Aust. J. Chem. 1980, 33, 885-890.

3. Izac, R.R.; Schneider, P.; Swain, M.; Fenical, W. New nor-sesquiterpenoids of apparent nardosinane origin from the pacific soft-coral Paralemnalia thyrsoides. Tetrahedron Lett. 1982, $23,817-820$.

4. Huang, H.-C.; Chao, C.-H.; Su, J.-H.; Hsu, C.-H.; Chen, S.-P.; Kuo, Y.-H.; Sheu, J.-H. Neolemnane-type sesquiterpenoids from a Formosan soft coral Paralemnalia thyrsoides. Chem. Pharm. Bull. 2007, 55, 876-880.

5. Wang, G.-H.; Huang, H.-C.; Su, J.-H.; Wu, Y.-C.; Sheu, J.-H. Paralemnolins J-P, new sesquiterpenoids from the soft coral Paralemnalia thyrsoide. Chem. Pharm. Bull. 2010, 58, 30-33.

6. Huang, H.-C.; Chao, C.-H.; Liao, J.-H.; Chiang, M.Y.; Dai, C.-F.; Wu, Y.-C.; Sheu, J.-H. A novel chlorinated norsesquiterpenoid and two related new metabolites from the soft coral Paralemnalia thyrsoides. Tetrahedron Lett. 2005, 46, 7711-7714.

7. Huang, H.-C.; Wen, Z.-H.; Chao, C.-H.; Ahmed, A.F.; Chiang, M.Y.; Kuo, Y.-H.; Hsu, C.-H.; Chen, S.-P; Sheu, J.-H. Novel sesquiterpenoids from the Formosan soft coral Paralemnalia thyrsoides. Tetrahedron Lett. 2006, 47, 8751-8755.

8. Daloze, D.; Braekman, J.C.; Georget, P.; Tursch, B. Chemical studies of marine invertebrates. XXII. Two novel sesquiterpenes from soft corals of the genera Lemnalia and Paralemnalia. Bull. Soc. Chim. Belg. 1977, 86, 47-54.

9. Bowden, B.F.; Coll, J.C.; Mitchell, S.J.; Skelton, B.W.; White, A.H. Studies of Australian soft corals. XXII. The structures of two novel sesquiterpenes and a nor sesquiterpene from Lemnalia africana, confirmed by a single-crystal X-ray study. Aust. J. Chem. 1980, 33, 2737-2747.

10. El-Gamal, A.A.; Chiu, E.-P.; Li, C.-H.; Cheng, S.Y.; Dai, C.-F.; Duh, C.-Y. Sesquiterpenoids and norsesquiterpenoids from the Formosan soft coral Lemnalia laevis. J. Nat. Prod. 2005, 68, 1749-1753.

11. Izac, R.R.; Fenical, W.; Tagle, B.; Clardy, J. Neolemnane and eremophilane sesquiterpenoids from the pacific soft coral Lemnalia africana. Tetrahedron 1981, 37, 2569-2573.

12. Lu, Y.; Li, P.-J.; Hung, W.-Y.; Su, J.-H.; Wen, Z.-H.; Hsu, C.-H.; Dai, C.-F.; Chiang, M.Y.; Sheu, J.-H. Nardosinane Sesquiterpenoids from the Formosan Soft Coral Lemnalia flava. J. Nat. Prod. 2011, 74, 169-174. 
13. Bishara, A.; Yeffet, D.; Sisso, M.; Shmul, G.; Schleyer, M.; Benayahu, Y.; Rudi, A.; Kashman, Y. Nardosinanols A-I and lemnafricanol, sesquiterpenes from several soft corals, Lemnalia sp., Paralemnalia clavata, Lemnalia africana, and Rhytisma fulvum fulvum. J. Nat. Prod. 2008, 71, 375-380.

14. Kapojos, M.M.; Mangindaan, R.E.; Nakazawa, T.; Oda, T.; Ukai, K.; Namikoshi, M. Three new nardosinane type sesquiterpenes from an Indonesian soft coral Nephthea sp. Chem. Pharm. Bull. 2008, 56, 332-334.

15. Bowden, B.F.; Coll, J.C.; Mitchell, S.J. Studies of Australian soft corals. XXIII. The co-occurrence of bicyclogermacrene and lemnacarnol derivatives in Parerythropodium fulvum. Tetrahedron Lett. 1980, 21, 3105-3108.

16. Ohtani, I.; Kusumi, T.; Kashman, Y.; Kakisawa, H. High-field FT NMR application of Mosher's method. The absolute configurations of marine terpenoids. J. Am. Chem. Soc. 1991, 113, 4092-4096.

17. Kitamura, Y.; Kosaka, T.; Kakimura, J.I.; Matsuoka, Y.; Kohno, I.; Nomura, Y.; Taniguchi, T. Protective effects of the antiparkinsonian drugs talipexole and pramipexole against 1-methyl-4-phenylpyridinium-induced apoptotic death in human neuroblastoma SH-SY5Y cells. Mol. Pharmacol. 1998, 54, 1046-1054.

18. Lee, K.Y.; Sung, S.H.; Kim, Y.C. Triterpenoids from Schisandra lancifolia with anti-HIV-1 activity. J. Nat. Prod. 2006, 69, 679-681.

19. Nakayama, G.R.; Caton, M.C.; Nova, M.P.; Parondoosh, Z. Assessment of the Alamar Blue assay for cellular growth and viability in vitro. J. Immunol. Methods 1997, 204, 205-208.

20. O'Brien, J.; Wilson, I.; Orton, T.; Pognan, F. Investigation of the Alamar Blue (resazurin) fluorescent dye for the assessment of mammalian cell cytotoxicity. Eur. J. Biochem. 2000, 267, $5421-5426$.

Samples Availability: Not available.

(C) 2011 by the authors; licensee MDPI, Basel, Switzerland. This article is an open access article distributed under the terms and conditions of the Creative Commons Attribution license (http://creativecommons.org/licenses/by/3.0/). 